\title{
OUTPERFORMING PEERS THROUGH A COMPREHENSIVE CLIMATE CHANGE STRATEGY: THE CASE OF ELECTRIC UTILITIES
}

\author{
Alexandra Schmidt \\ Panasonic Industry Europe GmbH • Ottobrunn, Germany \\ Anne Bergmann \\ Technische Universitaet Dresden • Germany \\ Julia Hillmann \\ Technische Universitaet Dresden • Germany \\ Edeltraud Guenther \\ Technische Universitaet Dresden • Germany
}

\section{ABSTRACT}

Firms increasingly aim to combat climate change. For corporate managers, the question whether a related strategy affects financial performance arises. Since empirical research on this topic is rather sparse, this study investigates whether pursuing a corporate climate change strategy leads to better corporate financial performance. By applying paired samples t-tests, a sample of 62 companies from the electric utilities sector matched in pairs is investigated over a five-year time span. Results indicate that firms with a comprehensive climate change strategy predominantly perform significantly better than their competitors without such a strategy. These findings might contribute to promoting climate change strategies in a corporate context.

Keywords: Climate change; Corporate climate change strategy; Corporate financial performance; Pairwise comparison; Matched-pair design; Paired samples t-test; Electric utilities.

\section{INTRODUCTION}

Climate change is considered one of the greatest long-term challenges facing society (Intergovernmental Panel on Climate Change, 2014; Steffen et al., 2015). It is a prominent and much debated ecological issue that challenges many business models, requires urgent action and, thus, is strategically relevant to organizations (Busch, 2011; Kolk \& Pinkse, 2004; Whiteman, Walker, \& Perego, 2013). Impacts of climate change occur at different spatial and time levels (Hoffmann, Sprengel, Ziegler, Kolb, \& Abegg, 2009) and therefore resulting risks are difficult to assess 
and, in addition, may lie outside of the organization's coping range (Linnenluecke \& Griffiths, 2012). Climate change induces complexity, uncertainty, and rapid change, which, in turn, requires organizations to respond proactively (Howard-Grenville, Buckle, Hoskins, \& George, 2014). To deal with climate change, a comprehensive climate change strategy, which combines the two response strategies mitigation and adaptation, is required (Intergovernmental Panel on Climate Change, 2014) and represents the focus of this paper.

Until now, mitigation and adaptation has been mainly investigated as two separate response strategies (Dlugolecki, 2008). Mitigation takes an inside-out perspective and represents the companies' efforts to reduce their impacts on the natural environment (Winn \& Kirchgeorg, 2005). Here, organizations mainly seek to reduce their greenhouse gas emissions (Weinhofer \& Hoffmann, 2010) or to offset them. However, scientists have suggested that even with planned mitigation, the increase in global temperatures and other harmful impacts are irreversible (Intergovernmental Panel on Climate Change, 2014). Therefore, adaptation - which takes the outside-in perspective (Winn \& Kirchgeorg, 2005) - represents the second response strategy in dealing with the impacts of climate change (Winn, Kirchgeorg, Griffiths, Linnenluecke, \& Guenther, 2011).

While mitigation is highly regulated by legislation (Kolk \& Pinkse, 2004), climate change adaptation is only partially in the hands of single states and is not as regulated worldwide (Gasbarro, Rizzi, \& Frey, 2016). Hence, mitigation strategies are rather clear for organizations, which is not the case for adaptation. Climate change adaptation represents a relatively new field which lacks clear signals from scientific communities, leading to confusion within organizations about the urgency and high barriers for investments in adaptation strategies (Gasbarro et al., 2016). The agricultural industry represents one example where rising temperatures might not only negatively impact firms, but might also lead to beneficial cases (Tate, Hughes, Temple, Boothby, \& Wilkinson, 2010). However, organizations need to realize that they are facing a 'new normal' (Howard-Greenville et al., 2014) and, thus, a climate change strategy that only consists of mitigation is not sufficient. Risks of climate change can only be substantially reduced when mitigation and adaptation efforts are combined (Intergovernmental Panel on Climate Change, 2014). Thus, organizations should strive for comprehensive response strategies that combine actions of mitigation as well as adaptation, as this will, following Beermann (2011) and Fankhauser, Smith, and Tol (1999), be crucial for organizations that aim to develop competitive advantages and reap financial benefits in spite of climate change. Actions to build pro-active response strategies further strengthen the strategic ability 
to develop necessary organizational skills to deal with a changing environment, which is fundamental for desirable organizational resilience (Limnios, Mazzarol, Ghadouani, \& Schilizzi, 2014).

After highlighting the importance of a climate change strategy that combines both mitigation and adaptation, it is rather astonishing that, until now, financial benefits of such a comprehensive climate change strategy have not yet been empirically investigated.

In order to analyze whether companies with a comprehensive climate change strategy financially outperform companies without such a comprehensive strategy, we apply a matched pair design that follows Michalisin and Stinchfield (2010). The contribution of such an empirical analysis is twofold. This study is the first to investigate accounting- as well as market-based financial benefits of a comprehensive climate change strategy that combines mitigation and adaptation. Second, we go beyond their analysis and offer a long-term perspective with a time lag analysis of four years.

Hence, an analysis that shows managers that companies with a comprehensive climate change strategy outperform their peers without one might be of interest and could lead those managers to opt for a more comprehensive climate change strategy.

This paper is organized as follows: We review related literature in section two and build up hypotheses in section three. Section four presents results which are then discussed in section five. We provide concluding remarks and avenues for future research in the last section of the paper.

\section{LITERATURE REVIEW}

\section{The Link between Climate Change Strategy and Financial Performance}

To date, only two prior studies have investigated the link between a corporate climate change strategy and corporate financial performance, each with different foci: the mitigation perspective (Michalisin \& Stinchfield, 2010) or the adaptation perspective (Stechemesser, Endrikat, Grasshoff, \& Guenther, 2015). Moreover, both studies focus on accounting-based measures for corporate financial performance and do not include measures for market-based financial performance or measures for market risk.

The study by Michalisin and Stinchfield, published in 2010, investigates the financial benefits of mitigation. Findings of this study show that firms with a climate change strategy have higher financial returns for return on assets (ROA), return on 
sales (ROS), and total asset turnover than their competitors without a mitigation strategy (Michalisin \& Stinchfield, 2010). They suggest that addressing climate change involves three strategic capability-based climate change strategies that achieve sustainable competitive advantage in a way that sustains natural resources and ecosystems: pollution prevention, product stewardship, and sustainable development (Michalisin \& Stinchfield, 2010). A meaningful aspect that should be underlined is the fact that the authors implicitly equate a so-called 'proactive climate change strategy' with mitigation. At the time, adaptation was not as discussed as it is today, which explains its specific focus on the mitigation perspective of a corporate climate change strategy.

The second, more recent study by Stechemesser et al. (2015) addresses the adaptation perspective on climate change and its relationship to financial performance. They investigate three capabilities that are related to and a result of engaging in climate change adaptation and investigate their link to ROA. Strategic climate change integration options include new insurance products and services, financing customer improvements, and (re-)investments in climate change solutions. The authors find no significant support for this relationship. However, they find that other climate change related capabilities are positively related to ROA, namely climate knowledge absorption and climate-related operational flexibility. One of the reasons for this might be the long-term characteristics of these capabilities as some time may be needed before the integration of climate change pays off. The authors further assume that a relationship is likely to be observed in the future due to the growing importance of climate change adaptation (Stechemesser et al., 2015).

Since literature on that specific link is sparse, we broadened the search to studies that deal with the more general topic of environmental strategies and their relation to financial performance since climate change strategies can be seen as a sub-category of environmental strategies. Findings from this literature show that a significant number of studies predominantly state a positive link (e.g. AragónCorrea, Hurtado-Torres, Sharma, \& García-Morales, 2008; Chan, 2010; Chan, 2005; Fergusson \& Langford, 2006; Sánchez-Ollero, García-Pozo, \& MarchanteLara, 2012). Some publications find a negative (Cainelli, Mazzanti, \& Zoboli, 2011; Cordeiro \& Sarkis, 1997) or simply no significant relationship at all (CarmonaMoreno, Céspedes-Lorente, \& De Burgos-Jiménez, 2004; Zaman Mir \& Shiraz Rahaman, 2011; Zhang, Wang, Yin, \& Su, 2012). Overall, findings on the influence of an environmental strategy on financial performance are inconclusive.

A more recent review of Mellahi, Frynas, Sun, and Siegel (2016) has proposed that all of these strategies can be subsumed under a more general strand called 
nonmarket strategies. They emphasize that all different variations of nonmarket strategies share similar mechanisms that explain the influence on organizational performance (Mellahi et al., 2016). However, even at this more collective level, the paper does not provide a clear conclusion on the link of nonmarket strategies to financial performance, which confirms the findings are inconclusive at best.

As an explanation, it could be argued that the implementation of an environmental strategy and its outcomes are generally difficult to measure and the strategy may reveal its effects rather in the long run than in the short run (Stechemesser et al., 2015). Friedman (1962) argued that social activities require financial and other, e.g. human, resources that are drained from value creating investments. While this argument might be valid in the short run, "in the long term, social and environmental issues become financial issues." (Sørenson, 2015, n.p.). As winner of the 2015 Harvard Business Review competition for 'The Best-Performing CEOs in the World', Sørenson (2015, n.p.) argued "Corporate social responsibility is nothing but maximizing the value of your company over a long period." Thus, trade-offs between short-term negative financial performance and long-term positive financial performance might occur. Moreover, financial performance of a company is also subject to many other influences related to the whole value chain and the availability of slack resources (Bergmann, Rotzek, Wetzel, \& Guenther, 2017). This means that firms with a high Corporate Financial Performance in the preceding years are more likely to invest in improved environmental performance in the following years as they have enough resources to do so (Modi \& Mishra, 2011).

Due to the inconclusiveness of the results, more future research is needed, especially on the topic of climate change strategies, where a significant research gap still exists (Boiral, Henri, \& Talbot, 2012; Michalisin \& Stinchfield, 2010).

\section{A Comprehensive Climate Change Strategy combines Mitigation with Adaptation}

While the value and necessity of climate change mitigation for companies has been studied extensively (see, for example, the review on climate change mitigation research of Glienke \& Guenther, 2016), there is only a small body of literature that addresses the adaptation perspective (Stechemesser et al., 2015). The adaptation debate started much later and gained momentum only after the publication of Rockström et al. (2009) on the planetary boundaries that suggested that mitigation efforts might be ineffective in addressing climate change risks (e.g., Buob \& Stephan, 2011; Nordhaus, 2006). Although climate change adaptation has become a central 
part of scientific debate (e.g., Berkhout, Hertin, \& Gann, 2006; Busch \& Hoffmann, 2009; Dlugolecki, 2008; Linnenluecke, Griffiths, \& Winn, 2012; Stechemesser et al., 2015), both strategies have been mostly discussed separately. Only recently have researchers started to examine the necessity to combine both strategies as this can create synergies (e.g., Bosello, Carraro, \& De Cian, 2013; Buob \& Stephan, 2011; Shalizi \& Lecocq, 2009).

Although most of those studies explain these benefits on the policy level, their findings can provide fruitful insights and explanations for why combining mitigation with adaptation at the company level is needed as well. Since mitigation concerns the reduction of emissions with the aim of minimizing the impact of climate change, the success of mitigation will determine the need for adaptation actions (Shalizi \& Lecocq, 2009). Studies repeatedly emphasized that individual countries have only limited control over total world emissions (Shalizi \& Lecocq, 2009) and, thus, the success of mitigation. Consequently, a single company has even less control, increasing the relevance of adaptation even more so. Having said this, however, does not render mitigation fruitless, as it depends on the ability to adapt (Shalizi \& Lecocq, 2009). Clement and Rivera (2017) show that companies, especially those from sectors that heavily rely on ecosystem services for adaptation, face adaptation limits if ecosystems shift and collapse. Therefore, mitigation is still suggested as the key to avoiding potentially catastrophic shifts.

Besides this, there are further reasons for companies to extend their climate change strategy to include adaptation. While mitigation is highly regulated by legislation (Kolk \& Pinkse, 2004), climate change adaptation is only partially in the hands of the state and is not as regulated worldwide as mitigation (Gasbarro et al., 2016), thus it is within the organizations' realm of control. Although there might be local policies and regulations that concern climate change adaptation, which is especially the case for firms acting in highly regulated sectors, it is the responsibility of the company to identify their exposure and vulnerability to climate change and to adapt accordingly. Therefore, a company's long-term success and sustained competitive advantage are as dependent on adaptation as they are on mitigation (Beermann, 2011; Fankhauser et al., 1999).

As expected, resources that are invested in mitigation cannot be invested in adaptation, but investing resources in mitigation on a global scale implies fewer resources for adaptation as it reduces the damage to which adaptation is needed (Barrett, 2008; Bosello et al., 2013; Tol, 2005). A successful response to climate change can only be materialized if mitigation efforts are combined with adaptation (Beerman, 2011; Linnenluecke \& Griffiths, 2012; Winn et al., 2011), 
which strengthens the strategic ability to develop necessary organizational skills to deal with a changing environment, a fundamental element for achieving desirable organizational resilience (Limnios et al., 2014).

Resilience is a "measure of the persistence of systems and their ability to absorb change and disturbance and still maintain the same relationships between populations or state variables" (Holling, 1973, p. 14). In the context of organizations, it has been translated into the ability of an organization to persist and absorb disturbances resulting from climate change (impact resistance) and the ability and time to recover from those disturbances (recovery) (Linnenluecke \& Griffiths, 2010; Linnenluecke et al., 2012). Organizations can apply different strategies to build impact resistance and recovery, i.e. resilience (Clement \& Rivera, 2017; Linnenluecke \& Griffiths, 2010). In the long term, companies that integrate climate change in their strategy can create resilience in terms of an increase in competitiveness through cost reduction, e.g. costs induced by new regulatory requirements, and thus gain independence from governmental agenda setting. Moreover, a differentiation strategy, e.g. offering green energy options to customers, can reduce the dependence on existing technologies. Risks can thereby be reduced and resilience of the companies enhanced. Both strategies - mitigation and adaptation - create organizational resilience, albeit through different mechanisms.

\section{HYPOTHESES DEVELOPMENT}

Since research on the linkage of corporate climate change strategy and corporate financial performance is sparse, we draw from existing research on the relationship between corporate environmental and corporate financial performance. Within this research stream, there have been various theoretical explanations for this relationship (Guenther \& Hoppe, 2014). For the relationship where corporate environmental performance predicts corporate financial performance, there are two theoretical explanations: value creation and trade-off theory (Guenther \& Hoppe, 2014). Considering the latter, Friedman (1962) was one of the first who argued that social activities require financial or human resources that, contemporaneously, cannot be used for other value creating businesses. Within the trade-off theory, scholars further claim that investments, such as in pollution control, negatively affect cash positions and, therefore, also lower profits. Following Mahapatra (1984), this further leads to an increased risk for the original investment.

A contrasting viewpoint for this line of reasoning is provided by several studies and meta studies in the field. One of the most recent meta studies includes more 
than 2,200 single analyses and its findings indicate an overall positive link between environmental, social, and governance criteria and corporate financial performance (Friede, Busch, \& Bassen, 2015). Hence, from an empirical point of view, the second perspective, also known as the value creation perspective, seems to better explain the link to financial performance. In addition to its empirical support, there are some other theoretical explanations for the value creation perspective. Following the argumentation of Guenther and Hoppe (2014), the 'it pays'-link is possible because a reduction in the usage of resources, emissions, or waste can be directly translated to a reduction of related costs (e.g. Judge \& Douglas, 1998; Nishitani, Kaneko, Fujii, \& Komatsu, 2011). Besides costs advantages, benefits might also stem from increased competitiveness through differentiation advantages on the product as well as on the firm level (McWilliams \& Siegel, 2000). Hence, customers might be willing to pay more as the offered product is environmentally friendly or the company can offer an enhanced environmental management system.

When it comes to climate change, the dichotomy of Friedman's argument and the anti-Friedman crowd might wane. At first glance, social responsibility can indeed be seen as a contradiction to a mere economic focus. When taking a broader view, however, it is quite rational for entrepreneurs to be socially responsible towards all stakeholders that might affect their financial performance, e.g. employees, the state, or suppliers. Thus, the ecological environment as a stakeholder in terms of decent climatic conditions might threaten or foster their financial performance and can be actively integrated into the business model.

Considering the study's focus on corporate climate change strategy, Michalisin and Stinchfield (2010) also favor the value creation perspective and draw on the Natural Resource Based View by Hart (1995) to explain the positive mechanisms behind a climate change strategy. These mechanisms can be seen in the development of three strategic capabilities (pollution prevention, product stewardship, and sustainable development). For the strategic capability of pollution prevention, they argue that reduced greenhouse gas emissions and a continuous improvement lead to lower costs which represent the basis for a sustainable competitive advantage. Second, competitors can be preempted by product stewardship through renewable energy sources and stakeholder participation. The third strategic capability of sustainable development requires a shared vision and leads the company to face global climate change problems (Michalisin \& Stinchfield, 2010).

The reason why corporate decision makers might not see those resulting benefits from proactive environmental business in general and comprehensive climate change strategies in particular might be due to insufficient information 
regarding possible profit opportunities (King \& Lenox, 2002). To sum up, the value creation perspective provides fruitful grounds for developing related hypotheses.

We follow the above-presented considerations and argue that firms can generate value through a comprehensive climate change strategy combining mitigation and adaptation strategies. Value generation occurs in terms of financial benefits that are internal (e.g. improved accounting-based financial performance) as well as external (e.g. improved market-based financial performance and reduced market risk).

Accounting-based measures represent backward looking measures of a firm's ability to use their assets efficiently and to generate value (Peloza, 2009). For instance, climate change mitigation strives to reduce fossil fuel utilization and carbon dioxide emissions, which redirects the energy sector towards low-carbon energy technologies (International Energy Agency, 2015a). Electric utilities, for example, can influence the supply side and increase water efficiency, reduce water use, or utilize municipal effluent for cooling (Ebinger \& Vergara, 2011; International Energy Agency, 2015b).

A major aspect of this redirection is the idea that pollution prevention is related to value maximization (Lanoie, Laplante, \& Roy, 1998; Porter \& Van der Linde, 1995). As several scholars, such as Michalisin and Stinchfield (2010), have already highlighted, pollution prevention leads to a reduced usage of additional resources. This potential is at the same time an indicator for the inefficient usage of resources (Hart \& Ahuja, 1996) because reduced consumption of resources includes resources that can be invested elsewhere and, ideally, create value. Furthermore, reduced resource usage and lower emissions help to avoid fines or liability costs. Product stewardship allows cost advantages to appear on the product level; thus, firms can sell green products for which customers are willing to pay a higher price, ultimately influencing sales outcomes such as ROS. On the firm level, environmental leadership, for instance, leads to learning curve advantages (Michalisin \& Stinchfield, 2010), which again leads to using assets more efficiently.

Adaptation measures can include investments in assets such as transmission and distribution systems (e.g., hardening and reinforcement) or specific asset design to improve impact resistance, ensuring functionality or fast recovery in the face of natural disasters (Ebinger \& Vergara, 2011; International Energy Agency, 2015b). Although costly, those measures can significantly reduce costs of restoration or outage-induced income losses. It can be expected that companies that are aware of this have planned accordingly and have applied related measures and, therefore, experience some stability in their accounting-based measures, even if the value 
creation hypothesis might not be the proper theory to explain benefits of adaptation measures. Another possibility to adapt to climate change can be achieved at the supply side by building redundancy and flexibility in the supply chain (e.g., Jüttner \& Maklan, 2011; Sheffi \& Rice, 2005). This further supports impact resistance and recovery and, in turn, can ensure stability in terms of sales and income. For example, companies that can ensure functionality or at least faster recovery avoid or reduce the need to purchase energy from competitors as they can ensure their own production. Thus, those companies still outperform their peers, although through a different mechanism.

Moreover, self-reinforcing effects when combining adaptation and mitigation might occur (Hallegatte, 2009; International Energy Agency, 2015b). This selfreinforcing effect in the case of companies can be seen in the stability created for the accounting-based measures in combination with potential changes in accountingbased measures through the positive effects of pollution prevention, product stewardship, and sustainable development. This allows companies to build more slack resources, which again can be reinvested and create a small advantage that over time accumulates and becomes an even stronger competitive advantage. We therefore expect that companies with a comprehensive climate change strategy experience positive effects for accounting-based financial performance.

Hypothesis 1: Companies pursuing a comprehensive climate change strategy financially outperform their competitors without such a strategy in terms of improved accounting-based financial performance.

Market-based financial performance measures reflect assumptions of investors about a firm's future developments (Balabanis, Phillips, \& Lyall, 1998; Endrikat, Guenther, \& Hoppe, 2014; Peloza, 2009) and also include intangible assets and reputational effects (Surroca, Tribó, \& Waddock, 2010). We hypothesize that the market and investors already perceive and value a comprehensive climate change strategy today for the following reasons:

Firms with a comprehensive climate change strategy take into account climate risks, prepare accordingly, and reduce their vulnerability. They reduce vulnerability in so far as they continuously anticipate and develop plans to detect further changes and act accordingly by building resilience. As companies cannot avoid all vulnerabilities, they develop strategies to deal with remaining vulnerabilities (e.g., Burnard \& Bhamra, 2011; McManus, Seville, Brunsdon, \& Vargo, 2007). They are also able to deal with unexpected events and to adjust to external changes 
without experiencing trauma (Burnard \& Bhamra, 2011; Hamel \& Välikangas, 2003; Linnenluecke et al., 2012). These activities contribute to stability in terms of less scrutiny and less unsystematic market risk (Ortiz-de-Mandojana \& Bansal, 2016). This represents a clear signal to market participants as they assess firms with a comprehensive climate change strategy as being less risky and better managed. Thus, we expect further benefits in terms of an improved market-based financial performance and a reduced market risk.

Hypothesis 2: Companies pursuing a comprehensive climate change strategy financially outperform their competitors without such a strategy in terms of improved market-based financial performance.

Hypothesis 3: Companies pursuing a comprehensive climate change strategy financially outperform their competitors without such a strategy in terms of reduced market risk.

\section{METHOD AND MATERIAL}

Our chosen sample focuses on the electric utilities industry as it represents a sector with high climate vulnerability since facilities are often located in climate sensitive areas (Busch, 2011; Gasbarro et al., 2016). Moreover, utilities need to rely on long-term assets and infrastructure resulting in high and long-term investments (Ebinger \& Vergara, 2011). Hence, as utilities cannot react in the short term regarding their assets, they have to carefully consider building climate change strategies and related resilience. This makes them a meaningful sample for this study. We rely on one distinct industry sector, as this is preferred when studying causality or change (Bono \& McNamara, 2011). In addition, we thereby enhance the comparability of the gained results and do not have to control for industry effects (Klassen \& Whybark, 1999).

An appropriate test design to compare companies pursuing a comprehensive climate change strategy with their competitors without such a strategy is represented by the method of pairwise comparison (matched-pair design). Michalisin and Stinchfield (2010) also decided to apply this method as it is preferable when attempting to determine if financial returns of so-called 'proactive' firms are significantly greater than those not considered 'proactive'.

First, electric utilities that report to the CDP were added to the sample. CDP provides the largest globally recognized database for information on climate 
change and companies (CDP, 2016; Kolk \& Pinkse, 2004). Furthermore, it offers important data for climate change related strategy analysis (Lewis, Walls, \& Dowell, 2014), which is, for instance, not the case for the Kinder, Lyndenberg, Domini \& Co. (KLD) Index. We, thus, select all electric utilities that reported to the CDP in 2012 (reported data refers to the year 2011) in order to expand the investigated time frame as suggested by Michalisin and Stinchfield (2010). Analyzing several years of data (2011-2015) reduces the impact exceptional events may have on a firm's financial performance, such as buying or selling power plants. It also allows for the consideration of the time lag between an action taken and its measured effect. In 2012, 52 electric utilities were listed in CDP and, out of those, 49 provided reports in English. Checking those 49 companies on whether they confirmed the integration of climate change into their business strategy reduced the sample size to 44 companies.

Second, we manually searched the Thomson Reuters Datastream database for electric utilities from the same country without an externally identifiable climate change strategy in order to match them with the CDP companies. We searched for company information on if and how they address climate change by applying a keyword search in the company's annual report, the corporate social responsibility report (if existent), and on the company's website. Besides the comparison of the country to minimize country-specific influences, for example legislation, the company size presents a decisive matching criterion. Following Bansal and Hunter (2003) and Michalisin and Stinchfield (2010), assets were chosen as a company size indicator. Since the ownership of power plants is a decisive feature of electric utility businesses, assets are a reasonable indicator for that industry sector. A comparable company, as defined by country and size, could not be identified for each of the 44 companies, which ultimately reduced the sample size to 31 pairs. These 31 pairs, i.e. 62 companies, stem from Europe $(n=16)$, North America $(n=26)$, South America $(\mathrm{n}=12)$, and Asia $(\mathrm{n}=8)$.

Following Michalisin and Stinchfield (2010), we then conducted a pairedsamples t-test to investigate the differences between the two pairs in terms of corporate financial performance. In contrast to the t-test for a single sample, the paired sample t-test uses difference scores and assumes that the population mean of the difference scores is 0 . A difference score entails the difference between the paired values from the two datasets. All difference scores are then treated as a single sample of scores during the hypothesis testing by calculating the mean and standard deviation of the difference scores in order to calculate the t-statistic (Aron, Coups, $\&$ Aron, 2011; Boslaugh, 2012). Therefore, the paired sample t-test can be seen as 
a single sample t-test on the difference scores (Weinberg \& Abramowitz, 2008) that basically tests for a statistical significant difference between matched pairs.

Measures of corporate financial performance stem from the Thomson Reuters Datastream. We rely on accounting-based as well as on market-based corporate financial performance measures. For accounting-based measures, we investigate the two profitability measures ROA and ROS as well as asset turnover as a measure for efficiency. For market-based financial performance measures, we rely on market value. Market risk is covered by the measures volatility and beta.

\section{RESULTS}

The final dataset derived from the matching process described in the previous section is verified by calculating the Pearson correlation coefficient in order to check for the correlation of the matched pairs regarding firm size (total assets values from 2011) (Michalisin \& Stinchfield, 2010). The results of this pre-test indicate that the matching process was effective since $r=0.989(p<0.001)$, which inevitably suggests a significant and very strong positive relationship.

Table 1 and Table 2 present statistics for the paired samples, including the means of each dataset, the number of companies in the dataset $(\mathrm{N})$, the standard deviation, and the standard error means. 


\section{Table 1}

Paired Samples Statistics for Accounting-Based Measures

\begin{tabular}{|c|c|c|c|c|c|c|}
\hline Measure & Year & Dataset & Mean & $\mathrm{N}$ & Std. Deviation & Std. Error mean \\
\hline \multirow[t]{10}{*}{ ROA } & \multirow{2}{*}{2011} & CDP companies & 0.043 & 29 & 0.040 & 0.007 \\
\hline & & MP companies & 0.007 & 29 & 0.052 & 0.009 \\
\hline & \multirow{2}{*}{2012} & CDP companies & 0.035 & 30 & 0.039 & 0.007 \\
\hline & & MP companies & 0.015 & 30 & 0.043 & 0.007 \\
\hline & \multirow{2}{*}{2013} & CDP companies & 0.032 & 31 & 0.037 & 0.006 \\
\hline & & MP companies & 0.016 & 31 & 0.036 & 0.006 \\
\hline & \multirow{2}{*}{2014} & CDP companies & 0.045 & 30 & 0.104 & 0.019 \\
\hline & & MP companies & 0.029 & 30 & 0.107 & 0.019 \\
\hline & \multirow{2}{*}{2015} & CDP companies & 0.026 & 30 & 0.018 & 0.003 \\
\hline & & MP companies & 0.011 & 30 & 0.030 & 0.005 \\
\hline \multirow[t]{10}{*}{ ROS } & \multirow{2}{*}{2011} & CDP companies & 0.137 & 31 & 0.167 & 0.030 \\
\hline & & MP companies & 0.010 & 31 & 0.248 & 0.044 \\
\hline & \multirow{2}{*}{2012} & CDP companies & 0.120 & 31 & 0.176 & 0.031 \\
\hline & & MP companies & 0.045 & 31 & 0.155 & 0.027 \\
\hline & \multirow{2}{*}{2013} & CDP companies & 0.124 & 31 & 0.199 & 0.035 \\
\hline & & MP companies & -0.248 & 31 & 1.741 & 0.312 \\
\hline & \multirow{2}{*}{2014} & CDP companies & 1.002 & 31 & 5.127 & 0.920 \\
\hline & & MP companies & 0.048 & 31 & 0.166 & 0.029 \\
\hline & \multirow{2}{*}{2015} & CDP companies & 0.282 & 30 & 1.065 & 0.194 \\
\hline & & MP companies & 0.046 & 30 & 0.136 & 0.024 \\
\hline \multirow{10}{*}{$\begin{array}{l}\text { Asset } \\
\text { turnover }\end{array}$} & \multirow{2}{*}{2011} & CDP companies & 0.405 & 30 & 0.237 & 0.043 \\
\hline & & MP companies & 0.422 & 30 & 0.225 & 0.041 \\
\hline & \multirow{2}{*}{2012} & CDP companies & 0.401 & 31 & 0.287 & 0.051 \\
\hline & & MP companies & 0.459 & 31 & 0.298 & 0.053 \\
\hline & \multirow{2}{*}{2013} & CDP companies & 0.397 & 31 & 0.247 & 0.044 \\
\hline & & MP companies & 0.387 & 31 & 0.215 & 0.038 \\
\hline & \multirow{2}{*}{2014} & CDP companies & 0.413 & 31 & 0.286 & 0.051 \\
\hline & & MP companies & 0.411 & 31 & 0.236 & 0.042 \\
\hline & \multirow{2}{*}{2015} & CDP companies & 0.391 & 30 & 0.279 & 0.051 \\
\hline & & MP companies & 0.419 & 30 & 0.283 & 0.051 \\
\hline
\end{tabular}


Table 2

\section{Paired Samples Statistics for Market-Based Measures}

\begin{tabular}{|c|c|c|c|c|c|c|}
\hline Measure & Year & Dataset & Mean & $\mathrm{N}$ & Std. Deviation & Std. Error mean \\
\hline \multirow{10}{*}{$\begin{array}{l}\text { Market } \\
\text { value }\end{array}$} & \multirow{2}{*}{2011} & CDP companies & 9231.138 & 30 & 9054.008 & 1653.028 \\
\hline & & MP companies & 6076.164 & 30 & 6271.958 & 1145.097 \\
\hline & \multirow{2}{*}{2012} & CDP companies & 9788.692 & 30 & 10317.888 & 1883.780 \\
\hline & & MP companies & 6101.368 & 30 & 6290.531 & 1148.488 \\
\hline & \multirow{2}{*}{2013} & CDP companies & 10334.082 & 30 & 11535.986 & 2106.173 \\
\hline & & MP companies & 6235.685 & 30 & 6800.241 & 1241.548 \\
\hline & \multirow{2}{*}{2014} & CDP companies & 10342.229 & 30 & 12144.155 & 2217.209 \\
\hline & & MP companies & 6485.765 & 30 & 6686.041 & 1220.698 \\
\hline & \multirow{2}{*}{2015} & CDP companies & 11630.082 & 30 & 14428.580 & 2634.286 \\
\hline & & MP companies & 6862.472 & 30 & 7506.929 & 1370.571 \\
\hline \multirow[t]{10}{*}{ Volatility } & \multirow{2}{*}{2011} & CDP companies & 0.234 & 30 & 0.114 & 0.020 \\
\hline & & MP companies & 0.296 & 30 & 0.110 & 0.020 \\
\hline & \multirow{2}{*}{2012} & CDP companies & 0.220 & 30 & 0.077 & 0.014 \\
\hline & & MP companies & 0.310 & 30 & 0.138 & 0.025 \\
\hline & \multirow{2}{*}{2013} & CDP companies & 0.193 & 30 & 0.065 & 0.011 \\
\hline & & MP companies & 0.286 & 30 & 0.142 & 0.025 \\
\hline & \multirow{2}{*}{2014} & CDP companies & 0.189 & 30 & 0.068 & 0.012 \\
\hline & & MP companies & 0.260 & 30 & 0.152 & 0.027 \\
\hline & \multirow{2}{*}{2015} & CDP companies & 0.193 & 31 & 0.077 & 0.013 \\
\hline & & MP companies & 0.266 & 31 & 0.143 & 0.025 \\
\hline \multirow[t]{10}{*}{ Beta } & \multirow{2}{*}{2011} & CDP companies & 0.550 & 26 & 0.308 & 0.060 \\
\hline & & MP companies & 0.738 & 26 & 0.453 & 0.088 \\
\hline & \multirow{2}{*}{2012} & CDP companies & 0.550 & 26 & 0.308 & 0.060 \\
\hline & & MP companies & 0.738 & 26 & 0.453 & 0.088 \\
\hline & \multirow{2}{*}{2013} & CDP companies & 0.550 & 26 & 0.308 & 0.060 \\
\hline & & MP companies & 0.738 & 26 & 0.453 & 0.088 \\
\hline & \multirow{2}{*}{2014} & CDP companies & 0.550 & 26 & 0.308 & 0.060 \\
\hline & & MP companies & 0.738 & 26 & 0.453 & 0.088 \\
\hline & \multirow{2}{*}{2015} & CDP companies & 0.550 & 26 & 0.308 & 0.060 \\
\hline & & MP companies & 0.738 & 26 & 0.453 & 0.088 \\
\hline
\end{tabular}

Table 3 provides the detailed paired sample t-test results. They are interpreted as follows: For example, the mean of the difference scores that is calculated from the 2011 ROA values of the CDP companies minus the 2011 ROA values of the matching pair (MP) companies is 0.036 . This difference is presumed to be not attributable to chance since $\mathrm{p}<0.01$ indicates that the ROA of CDP companies is significantly better (higher) than the ROA of MP companies, thus rejecting H0. The same applies for the ROA values of $2012(\mathrm{p}<0.05), 2013(\mathrm{p}<0.1)$, and $2015(\mathrm{p}<0.05)$. 
Table 3

\section{Results of Paired Samples T-Tests}

\begin{tabular}{|c|c|c|c|c|c|c|c|}
\hline Measure & Year & Mean & Std. Deviation & Std. Error mean & $\mathrm{t}$ & $\mathrm{df}$ & Sig. (2-tailed) \\
\hline \multirow[t]{5}{*}{ ROA } & 2011 & 0.036 & 0.044 & 0.008 & 4.366 & 28 & $0.000 * * *$ \\
\hline & 2012 & 0.019 & 0.050 & 0.009 & 2.179 & 29 & $0.038 * *$ \\
\hline & 2013 & 0.016 & 0.048 & 0.008 & 1.915 & 30 & $0.065^{*}$ \\
\hline & 2014 & 0.015 & 0.144 & 0.026 & 0.579 & 29 & 0.567 \\
\hline & 2015 & 0.014 & 0.032 & 0.005 & 2.441 & 29 & $0.021^{* *}$ \\
\hline \multirow[t]{5}{*}{ ROS } & 2011 & 0.126 & 0.268 & 0.0481 & 2.628 & 30 & $0.013 * *$ \\
\hline & 2012 & 0.075 & 0.225 & 0.040 & 1.863 & 30 & $0.072 *$ \\
\hline & 2013 & 0.372 & 1.739 & 0.312 & 1.193 & 30 & 0.242 \\
\hline & 2014 & 0.953 & 5.113 & 0.918 & 1.038 & 30 & 0.307 \\
\hline & 2015 & 0.236 & 1.043 & 0.190 & 1.243 & 29 & 0.224 \\
\hline \multirow{5}{*}{$\begin{array}{l}\text { Asset } \\
\text { turnover }\end{array}$} & 2011 & -0.017 & 0.221 & 0.040 & -0.422 & 29 & 0.676 \\
\hline & 2012 & -0.058 & 0.304 & 0.054 & -1.063 & 30 & 0.296 \\
\hline & 2013 & 0.009 & 0.222 & 0.039 & 0.249 & 30 & 0.805 \\
\hline & 2014 & 0.002 & 0.214 & 0.038 & 0.054 & 30 & 0.958 \\
\hline & 2015 & -0.027 & 0.219 & 0.040 & -0.692 & 29 & 0.495 \\
\hline \multirow{5}{*}{$\begin{array}{l}\text { Market } \\
\text { value }\end{array}$} & 2011 & 3154.973 & 6743.653 & 1231.217 & 2.562 & 29 & $0.016^{* *}$ \\
\hline & 2012 & 3687.323 & 7917.963 & 1445.615 & 2.551 & 29 & $0.016^{* *}$ \\
\hline & 2013 & 4098.397 & 8784.167 & 1603.762 & 2.555 & 29 & $0.016^{* *}$ \\
\hline & 2014 & 3856.463 & 9173.411 & 1674.828 & 2.303 & 29 & $0.029 * *$ \\
\hline & 2015 & 4767.610 & 9691.037 & 1769.333 & 2.695 & 29 & $0.012 * *$ \\
\hline \multirow[t]{5}{*}{ Volatility } & 2011 & -0.062 & 0.171 & 0.031 & -1.991 & 29 & $0.056^{*}$ \\
\hline & 2012 & -0.090 & 0.166 & 0.030 & -2.970 & 29 & $0.006^{* * *}$ \\
\hline & 2013 & -0.093 & 0.161 & 0.029 & -3.154 & 29 & $0.004 * * *$ \\
\hline & 2014 & -0.070 & 0.160 & 0.029 & -2.425 & 29 & $0.022 * *$ \\
\hline & 2015 & -0.072 & 0.152 & 0.027 & -2.663 & 30 & $0.012 * *$ \\
\hline \multirow[t]{5}{*}{ Beta } & 2011 & -0.188 & 0.439 & 0.086 & -2.189 & 25 & $0.038^{* *}$ \\
\hline & 2012 & -0.188 & 0.439 & 0.086 & -2.189 & 25 & $0.038^{* *}$ \\
\hline & 2013 & -0.188 & 0.439 & 0.086 & -2.189 & 25 & $0.038^{* *}$ \\
\hline & 2014 & -0.188 & 0.439 & 0.086 & -2.189 & 25 & $0.038^{* *}$ \\
\hline & 2015 & -0.188 & 0.439 & 0.086 & -2.189 & 25 & $0.038^{* *}$ \\
\hline
\end{tabular}

$* * *=$ the paired samples t-test is significant at the 0.01 level

$* *=$ the paired samples $t$-test is significant at the 0.05 level

$* \quad=$ the paired samples t-test is significant at the 0.1 level

As the paired samples statistics in Table 1 show, the means of the CDP companies are better for ROA and ROS over the entire investigated five-year timeframe. However, as shown in Table 3 , the results are only statistically significant for four years of ROA and two years of ROS. Therefore the findings of Michalisin and Stinchfield (2010) can be confirmed for ROA and ROS. However, no evidence for higher asset turnover is found since the results do not suggest significant differences between the two investigated groups at all (see Table 3). The means themselves are better (higher) for two years each (see Table 1). 
Considering the analyzed measures for market-based financial performance and market risk, namely market value, volatility, and beta, the conducted paired samples t-tests indicate significant results for all investigated years (see Table 3). These results further suggest that a comprehensive climate change strategy leads to better corporate financial performance, particularly in terms of market value and market risk.

To sum up, the results of the paired samples t-test show that electric utilities pursuing a comprehensive climate change strategy usually perform significantly better than their peers.

\section{DISCUSSION}

Since no empirical study that assesses the influence of comprehensive climate change strategies on the corporate market-based performance is known, this study presents unique findings. In comparison to Michalisin and Stinchfield (2010), who published a static analysis (two-year average, 2005 - 2006), the results of this study are more comprehensive and meaningful due to the larger dataset investigated. In summary, the results of the hypotheses testing indicate that electric utility companies pursuing a comprehensive climate change strategy predominantly outperform their comparable competitors without such a strategy in terms of corporate financial performance. Thus, the presented results not only confirm our underlying theoretical explanation, the value creation perspective, in several ways, but they also refine it: The results regarding accounting performance measures confirm Michalisin and Stinchfield's (2010) findings of significantly higher mean values for ROA and ROS. However, results are not as clear for asset turnover. Asset turnover is a measure for the company's efficiency in terms of how well it uses its assets. Companies with a climate change strategy build resilience which is associated with building redundancies, thus being contradictory to efficiency. Therefore, a comprehensive climate change strategy might affect this particular financial ratio differently. However, as mentioned in the hypothesis section, companies that build resilience are able to provide some kind of stability by, for example, avoiding long lasting outages in the case of a disturbance due to faster recovery. Thus, there are mixed arguments for the influence of a climate change strategy on asset turnover.

On the contrary, the results for market-based measures are clearer. Our results indicate a stronger relationship between climate change strategy and marketbased measures. One of the reasons could be the long-term characteristic of climate strategies that find expression in the more long-term oriented market-based measures. 
In contrast, accounting-based measures represent a short-term orientation. This is in line with other publications that rely on the long-term positive influence of climate strategies (e.g., Cainelli et al., 2011; Cordeiro \& Sarkis, 1997; Stechemesser et al., 2015; Zhang et al., 2012). Another explanation for the strong positive relationship of climate change strategy and market-based measures is the reputational benefit proactive managers can trigger with deliberations on how to position the company with regard to future challenges (Surroca et al., 2010). As climate change is perceived to be an important risk factor (Kreft, Eckstein, \& Melchior, 2017), companies that integrate the expected risks in their company policy are perceived to be more resilient when facing future challenges like climate change.

Investors seeking possibilities to assess a company's comprehensive climate change activity might be particularly interested in this possible positive relationship to market value and market risk and might be encouraged to consider CDP as an indicator for a better performance of companies (Guenther, Guenther, Schiemann, $\&$ Weber, 2016). In addition, two other explanations for the differing results for market- and accounting-based measures are possible: the electric utility sector is highly regulated in many countries and the companies might have the possibility to transfer the costs for adaptation measures to customers or the state, which is, for example, the case in Germany with the German Renewable Energy Law. For instance, costs for more resilient grids can directly be incorporated in the pricing policy; thus, the firms' profitability is not affected. As electricity demand is usually considered to be rather inelastic, net sales of electric utility companies may not vary much in general and may therefore not be influenced by a climate change strategy. Finally, if we delve deeper into the observed relationships, we could seek out for drivers behind the applied measures. A comprehensive climate change strategy can be an indicator for good corporate governance in general, increased accountingbased performance can be achieved due to increased efficiency, and increased market-based performance can be attributed to an increased awareness of the general public concerning climate change (Kock, Santaló, \& Diestre, 2012).

However, it is important to keep in mind that we cannot judge what executives really think based on the analysis of CDP data. Thus, our results and their interpretation are based on the assumption that CDP data reflects the real intention of the companies and that they actually 'walk the talk'. It could be argued that CDP disclosure might also be used for greenwashing (Delmas \& Burbano, 2011). In this case, the result that firms with a comprehensive climate change strategy outperform their competitors without such a strategy would mean that companies with a higher level of greenwashing perform better. For market-based measures this result could 
be explained by investors who have been misled, but for accounting-based measures this conclusion does not hold. Thus, we interpret the accounting-based measures as robustness indicators for honest response behavior.

\section{CONCLUSION}

Results of this empirical research provide evidence that electric utilities with a comprehensive climate change strategy outperform their matched peers, particularly in terms of market value and market risk.

Having analyzed financial impacts of climate change strategies within a climate sensitive industry, this conclusion will, first of all, elaborate possible questions for future research. Results of this paper provide evidence that, indeed, strategy matters and, thus, empirical analyses on the link of climate change and financial performance should include variables for strategic performance. In other words, future research should not only rely on mere operational data such as $\mathrm{CO}_{2}$ emissions. Moreover, since time matters for empirical analyses, we therefore encourage future research to avoid using concurrent measures. Considering the measures for financial performance, both accounting and market-based measures should be considered within future studies. A final conclusion for future research can be drawn on a meta-level concerning the type of analysis: In contrast to medical research, where matched-pair tests represent a state-of-the-art method, they remain rare in economic analyses. As the comparison of two similar firms allows for a specific focus on the differentiating item to be analyzed (in our case, climate change strategy), more studies based on this design could contribute to a better understanding of success factors. For scholars, the mere process of matching the pairs provides deep insights into corporate practices and can even be superior to only considering confounding variables by accounting for moderators.

Besides the presented ideas for future research, this conclusion also provides possible implications for investors, top managers, and politicians. Investors gain the knowledge that CDP is a good indicator and easy to grasp. Moreover, investors learn that, considering the long-term perspective, climate change strategy is not a tradeoff for performance. Top managers can use the results to learn that a comprehensive climate change strategy is a means for improving performance and reducing risk as is also the case for the highly regulated electric utilities sector. Hence, the value creation perspective should receive more attention from top management. Instead of asking the question of whether a comprehensive climate change strategy pays off, they should try to influence climate change drivers for financial success. Finally, this 
research can inspire and encourage politicians to cope with climate change, either by mitigation or by adaptation, as opposed to being afraid that such measures could endanger economic growth.

\section{REFERENCES}

Aragón-Correa, J. A., Hurtado-Torres, N., Sharma, S., \& García-Morales, V. J. (2008). Environmental strategy and performance in small firms: A resourcebased perspective. Journal of Environmental Management, 86(1), 88-103. doi:10.1016/j.jenvman.2006.11.022

Aron, A., Coups, E. J., \& Aron, E. 2011. Statistics for the behavioral and social sciences: a brief course (5. ed). Boston: Prentice Hall.

Balabanis, G., Phillips, H. C., \& Lyall, J. (1998). Corporate social responsibility and economic performance in the top British companies: are they linked? European Business Review, 98(1), 25-44.

Bansal, P., \& Hunter, T. (2003). Strategic explanations for the early adoption of ISO 14001. Journal of Business Ethics, 46(3), 289-299.

Barrett, S. (2008). Dikes vs. windmills: climate treatise and adaptation. Discussion Paper, Johns Hopkins University, Baltimore, MD.

Beermann, M. (2011). Linking corporate climate adaptation strategies with resilience thinking. Journal of Cleaner Production, 19(8), 836-842. doi:10.1016/j. jclepro.2010.10.017

Bergmann, A., Rotzek, J. N., Wetzel, M., \& Guenther, E. (2017). Hang the lowhanging fruit even lower - Evidence that energy efficiency matters for corporate financial performance. Journal of Cleaner Production, 147, 66-74. doi:10.1016/j.jclepro.2017.01.074

Berkhout, F., Hertin, J., \& Gann, D. (2006). Learning to adapt: organisational adaptation to climate change impacts. Climatic Change, 78(1), 135-156.

Boiral, O., Henri, J.-F., \& Talbot, D. (2012). Modeling the impacts of corporate commitment on climate change. Business Strategy and the Environment, 21(8), 495-516. doi:10.1002/bse.723

Bono, J. E., \& McNamara, G. (2011). Publishing in AMJ - Part 2: Research Design. Academy of Management Journal, 54(4), 657-660. doi:10.5465/ AMJ.2011.64869103

Bosello, F., Carraro, C., \& De Cian, E. (2013). Adaptation can help mitigation: an integrated approach to post-2012 climate policy. Environment and Development Economics, 18(3), 270-290. doi:10.1017/S1355770X13000132 
Boslaugh, S. 2012. Statistics in a nutshell (2nd ed). Farnham, Surrey, England: O'Reilly.

Buob, S., \& Stephan, G. (2011). To mitigate or to adapt: How to confront global climate change. European Journal of Political Economy, 27(1), 1-16. doi:10.1016/j.ejpoleco.2010.05.001

Burnard, K., \& Bhamra, R. (2011). Organisational resilience: development of a conceptual framework for organisational responses. International Journal of Production Research, 49(18), 5581-5599. doi:10.1080/00207543.2011.563827

Busch, T. (2011). Organizational adaptation to disruptions in the natural environment: The case of climate change. Scandinavian Journal of Management, 27(4), 389404.

Busch, T., \& Hoffmann, V. H. (2009). Ecology-driven real options: an investment framework for incorporating uncertainties in the context of the natural environment. Journal of Business Ethics, 90(2), 295-310. doi:10.1007/s10551009-0043-y

Cainelli, G., Mazzanti, M., \& Zoboli, R. (2011). Environmentally oriented innovative strategies and firm performance in services. Micro-evidence from Italy. International Review of Applied Economics, 25(1), 61-85. doi:10.1080/02692170903426146

Carmona-Moreno, E., Céspedes-Lorente, J., \& Burgos-Jiménez, J. de. (2004). Environmental strategies in Spanish hotels: contextual factors and performance. The Service Industries Journal, 24(3), 101-130. doi:10.1080/0264206042000247786

CDP. (2016). Catalyzing Business and Government Action. Retrieved from https:// www.cdp.net/en-US/Pages/About-Us.aspx

Chan, R. Y. K. (2005). Does the natural-resource-based view of the firm apply in an emerging economy? A survey of foreign invested enterprises in China. Journal of Management Studies, 42(3), 625-672.

Chan, R. Y. (2010). Corporate environmentalism pursuit by foreign firms competing in China. Journal of World Business, 45(1), 80-92. doi:10.1016/j.jwb.2009.04.010

Clement, V. \& Rivera, J. (2017). From adaptation to transformation: An extended research agenda for organizational resilience to adversity in the natural environment. Organization \& Environment, 30(4), 346-365. doi:10.1177/1086026616658333 
Cordeiro, J. J., \& Sarkis, J. (1997). Environmental proactivism and firm performance: evidence from security analyst earnings forecasts. Business Strategy and the Environment, 6(2), 104-114. doi:10.1002/(SICI)10990836(199705)6:2<104::AID-BSE102>3.0.CO;2-T

Delmas, M.A. \& Cuerel Burbano, C. (2011). The Drivers of Greenwashing. California Management Review, 54(1), 64-87. doi: 10.1525/cmr.2011.54.1.64

Dlugolecki, A. (2008). Climate change and the insurance sector. The Geneva Papers on Risk and Insurance - Issues and Practice. 33(1), 71-90. doi: 10.1057/ palgrave.gpp. 2510152

Ebinger, J. O., \& Vergara, W. (2011). Climate impacts on energy systems: Key issues for energy sector adaptation. A World Bank study. Washington, D.C: World Bank.

Endrikat, J., Guenther, E., \& Hoppe, H. (2014). Making sense of conflicting empirical findings: A meta-analytic review of the relationship between corporate environmental and financial performance. European Management Journal, 32(5), 735-751. doi:10.1016/j.emj.2013.12.004

Fankhauser, S., Smith, J. B., \& Tol, R. S. (1999). Weathering climate change: some simple rules to guide adaptation decisions. Ecological Economics, 30(1), 67-78. doi:10.1016/S0921-8009(98)00117-7

Fergusson, H., \& Langford, D. (2006). Strategies for managing environmental issues in construction organizations. Engineering, Construction and Architectural Management, 13(2), 171-185. doi:10.1108/09699980610659625

Friede, G., Busch, T., \& Bassen, A. (2015). ESG and financial performance: aggregated evidence from more than 2000 empirical studies. Journal of Sustainable Finance \& Investment, 5(4), 210-233. doi:10.1080/20430795.201 5.1118917

Friedman, M. (1962). Capitalism and freedom. Chicago: University of Chicago Press.

Gasbarro, F., Rizzi, F., \& Frey, M. (2016). Adaptation measures of energy and utility companies to cope with water scarcity induced by climate change. Business Strategy \& the Environment, 25(1), 54-72. doi:10.1002/bse.1857

Glienke, N., \& Guenther, E. (2016). Corporate climate change mitigation: a systematic review of the existing empirical evidence. Management Research Review, 39(1), 2-34. doi:10.1108/MRR-10-2013-0243

Guenther, E., Guenther, T., Schiemann, F., \& Weber, G. (2016). Stakeholder relevance for reporting: explanatory factors of carbon disclosure. Business \& Society, 55(3), 361-397. doi:10.1177/0007650315575119 
Guenther, E. M., \& Hoppe, H. (2014). Merging limited perspectives. Journal of Industrial Ecology, 18(5), 689-707. doi:10.1111/jiec.12125

Hallegatte, S. (2009). Strategies to adapt to an uncertain climate change. Global Environmental Change, 19(2), 240-247. doi:10.1016/j.gloenvcha.2008.12.003 Hamel, G., \& Välikangas, L. (2003). The Quest for Resilience. Harvard Business Review, 81(9), 52-63.

Hart, S. L. (1995). A natural-resource-based view of the firm. Academy of Management Review, 20(4), 986-1014. doi:10.5465/AMR.1995.9512280033

Hart, S. L., \& Ahuja, G. (1996). Does it pay to be green? An empirical examination of the relationship between emission reduction and firm performance. Business Strategy and the Environment, 5(1), 30-37.

Hoffmann, V. H., Sprengel, D. C., Ziegler, A., Kolb, M., \& Abegg, B. (2009). Determinants of corporate adaptation to climate change in winter tourism: An econometric analysis. Global Environmental Change, 19(2), 256-264. doi:10.1016/j.gloenvcha.2008.12.002

Holling, C. S. (1973). Resilience and Stability of Ecological Systems. Annual Review of Ecology and Systematics, 4, 1-23.

Howard-Grenville, J., Buckle, S., Hoskins, B., \& George, G. (2014). From the editors: climate change and management. Academy of Management Journal, 57(3), 615-623. doi:10.5464/amj.2014.4003

Intergovernmental Panel on Climate Change. (2014). Climate change 2014: synthesis report. Contribution of working groups I, II and III to the fifth assessment report of the intergovernmental panel on climate change. Geneva.

International Energy Agency. (2015a). Energy and climate Change. World energy outlook special report. Retrieved from https://www.iea.org/publications/free publications/publication/WEO2015SpecialReportonEnergyandClimateChange.pdf International Energy Agency. (2015b). Making the energy sector more resilient to climate change. Retrieved from https:/www.iea.org/publications/ freepublications/publication/COP21_Resilience_Brochure.pdf

Judge, W., \& Douglas, T. (2009). Organizational change capacity: the systematic development of a scale. Journal of Organizational Change Management, 22(6), 635-649. doi:10.1108/09534810910997041

Jüttner, U., \& Maklan, S. (2011). Supply chain resilience in the global financial crisis: an empirical study. Supply Chain Management: An International Journal, 16(4), 246-259. doi:10.1108/13598541111139062 
King, A. A., \& Lenox, M. J. (2000). Industry self-regulation without sanctions: the chemical industry's responsible care program. Academy of Management Journal, 43(4), 698-716. doi:10.2307/1556362

Klassen, R. D., \& Whybark, D. C. (1999). The impact of environmental technologies on manufacturing performance. Academy of Management Journal, 42(6), 599615. doi:10.2307/256982

Kock, C. J., Santaló, J., \& Diestre, L. (2012). Corporate governance and the environment: what type of governance creates greener companies? Journal of Management Studies, 49(3), 492-514. doi:10.1111/j.1467-6486.2010.00993.x

Kolk, A., \& Pinkse, J. (2004). Market Strategies for Climate Change. European Management Journal, 22(3), 304-314. doi:10.1016/j.emj.2004.04.011

Kreft, S., Eckstein, D., \& Melchior, I. Global climate risk index 2017: who suffers most from extreme weather events? Weather-related loss events in 2015 and 1996 to 2015.

Lanoie, P., Laplante, B., \& Roy, M. (1998). Can capital markets create incentives for pollution control? Ecological Economics, 26(1), 31-41. doi:10.1016/S09218009(97)00057-8

Lewis, B. W., Walls, J. L., \& Dowell, G. W. S. (2014). Difference in degrees: CEO characteristics and firm environmental disclosure. Strategic Management Journal, 35(5), 712-722. doi:10.1002/smj.2127

Limnios, E. A. M., Mazzarol, T., Ghadouani, A., \& Schilizzi, S. G. M. (2014). The resilience architecture framework: four organizational archetypes. European Management Journal, 32(1), 104-116. doi:10.1016/j.emj.2012.11.007

Linnenluecke, M. K., \& Griffiths, A. (2012). Assessing organizational resilience to climate and weather extremes: complexities and methodological pathways. Climatic Change, 113(3-4), 933-947. doi:10.1007/s10584-011-0380-6

Linnenluecke, M., \& Griffiths, A. (2010). Beyond Adaptation: Resilience for Business in Light of Climate Change and Weather Extremes. Business \& Society, 49(3), 477-511. doi:10.1177/0007650310368814

Linnenluecke, M. K., Griffiths, A., \& Winn, M. (2012). Extreme weather events and the critical importance of anticipatory adaptation and organizational resilience in responding to impacts. Business Strategy \& the Environment, 21(1), 17-32. doi:10.1002/bse. 708

Mahapatra, S. (1984). Investor reaction to a corporate social accounting. Journal of Business Finance \& Accounting, 11(1), 29-40. doi:10.1111/j.1468-5957.1984. tb00054.x 
McManus, S., Seville, E., Brunsdon, D., \& Vargo, J. (2007). Resilience Management: A Framework for assessing and Improving the resilience of organisations. Retrieved from http://www.resorgs.org.nz

McWilliams, A., \& Siegel, D. (2000). Corporate social responsibility and financial performance: correlation or misspecification? Strategic Management Journal, 21(5), 603-609. doi:10.1002/(SICI)1097-0266(200005)21:5<603::AIDSMJ101>3.0.CO;2-3

Mellahi, K., Frynas, J.G., Sun, P \& Siegel, D. (2016). A review of the nonmarket strategy literature: toward a multi-theoretical integration. Journal of Management 42(1), 143-173. doi:10.1177/0149206315617241

Michalisin, M. D., \& Stinchfield, B. T. (2010). Climate change strategies and firm performance: an empirical investigation of the natural resource- based view of the firm. Journal of Business Strategies, 27(2), 123-149.

Modi, S.B., Mishra, S., 2011. What drives financial performance - resource efficiency or resource slack? Journal of Operations Management, 29(3), 254273. doi:10.1016/j.jom.2011.01.002

Nishitani, K., Kaneko, S., Fujii, H., \& Komatsu, S. (2011). Effects of the reduction of pollution emissions on the economic performance of firms: an empirical analysis focusing on demand and productivity. Journal of Cleaner Production, 19(17-18), 1956-1964. doi:10.1016/j.jclepro.2011.06.021

Nordhaus, W. D. (2006). After Kyoto: Alternative mechanisms to control global warming. American Economic Review, 96(2), 31-34. doi:10.1257/000282806777211964

Ortiz-de-Mandojana, N., \& Bansal, P. (2016). The long-term benefits of organizational resilience through sustainable business practices. Strategic Management Journal, 37(8), 1615-1631. doi:10.1002/smj.2410

Peloza, J. (2009). The challenge of measuring financial impacts from investments in corporate social performance. Journal of Management, 35(6), 1518-1541. doi: $10.1177 / 0149206309335188$

Porter, M. E., \& van der Linde, C. (1995). Toward a new conception of the environment-competitiveness relationship. Journal of Economic Perspectives, 9(4), 97-118. doi:10.1257/jep.9.4.97

Rockström, J., Steffen, W., Noone, K., Persson, A., Chapin III, F. S., Lambin, E. F., \& et al. (2009). A safe operating space for humanity. Nature, 461(7263), 472-475. doi:10.1038/461472a 
Sánchez-Ollero, J. L., García-Pozo, A., \& Marchante-Lara, M. (2012). Environment and strategic behaviour: the case of hotels in Andalusia (Spain). International Journal of Environmental Research, 6(4), 1067-1076. doi:10.22059/ ijer.2012.577

Shalizi, Z., \& Lecocq, F. (2010). To mitigate or to adapt: Is that the question? Observations on an appropriate response to the climate change challenge to development strategies. The World Bank Research Observer, 25(2), 295-321. doi:10.1093/wbro/lkp012

Sheffi, Y., \& Rice, J. B. (2005). A supply chain view of the resilient enterprise. MIT Sloan Management Review, 47(1), 41-48

Sørenson, L. R. (2015). The best-performing CEOs in the world. Retrieved from https://hbr.org/2015/11/the-best-performing-ceos-in-the-world\%20Lars\%20 S\%C3\%B8rensen\%20(Novo\%20Nordisk) \%E2\%80\%9D

Stechemesser, K., Endrikat, J., Grasshoff, N., \& Guenther, E. (2015). Insurance companies' responses to climate change: adaptation, dynamic capabilities and competitive advantage. The Geneva Papers on Risk and Insurance Issues and Practice, 40(4), 557-584. doi:10.1057/gpp.2015.1

Steffen, W., Richardson, K., Rockstrom, J., Cornell, S. E., Fetzer, I., Bennett, E. M. et al. (2015). Planetary boundaries: Guiding human development on a changing planet. Science, 347(6223). 1259855-1-1259855-10. doi:10.1126/ science. 1259855

Surroca, J., Tribó, J. A., \& Waddock, S. (2010). Corporate responsibility and financial performance: the role of intangible resources. Strategic Management Journal, 31(5), 463-490. doi:10.1002/smj.820

Tate, G., Hughes, G., Temple, M., Boothby, D., \& Wilkinson, M. (2010). Changes to farm business management under extreme weather events: Likelihood of effects and opportunities in the UK. Journal of Farm Management, 14(1), 67-86.

Tol, R.S.J. (2005). Adaptation and mitigation: trade-offs in substance and methods. Environmental Science and Policy, 8(6), 572-578.

Weinberg, S. L., \& Abramowitz, S. K. (2008). Statistics using SPSS: an integrative approach (2nd ed). Cambridge, New York: Cambridge University Press.

Weinhofer, G., \& Hoffmann, V. H. (2010). Mitigating climate change - how do corporate strategies differ?. Business Strategy and the Environment. 19(2), 7789. doi:10.1002/bse.618

Whiteman, G., Walker, B., \& Perego, P. (2013). Planetary boundaries: ecological foundations for corporate sustainability. Journal of Management Studies, 50(2), 307-336. doi:10.1111/j.1467-6486.2012.01073.x 
Winn, M. I., \& Kirchgeorg, M. (2005). The siesta is over: a rude awakening from sustainability myopia. In S. Sharma \& J. Aragón-Correa (Eds.), Corporate Environmental Strategy and Competitive Advantage. Edward Elgar Publishing. Winn, M., Kirchgeorg, M., Griffiths, A., Linnenluecke, M. K., \& Günther, E. (2011). Impacts from climate change on organizations: a conceptual foundation. Business Strategy \& the Environment, 20(3), 157-173.

Zaman Mir, M., \& Shiraz Rahaman, A. (2011). In pursuit of environmental excellence. Accounting, Auditing \& Accountability Journal, 24(7), 848-878. doi:10.1108/09513571111161620

Zhang, B., Wang, Z., Yin, J., \& Su, L. (2012). CO2 emission reduction within Chinese iron \& steel industry: practices, determinants and performance. Journal of Cleaner Production, 33, 167-178. doi:10.1016/j.jclepro.2012.04.012

\section{BIOGRAPHICAL SKETCH OF AUTHORS}

Alexandra Schmidt studied at Technische Universitaet Dresden and ESC Rennes School of Business. She received a B.Sc. in Business and Economics and a M.Sc. in Business Management. Her main focus was on Environmental Management, Sustainability and Energy Economics. Currently she is working in the electronic industry at Panasonic Industry Europe $\mathrm{GmbH}$ as Environment \& CSR Officer specializing on Recycling, Environmental Product Compliance and Corporate Social Responsibility.

Dr. Anne Bergmann studied Industrial Engineering and Management at the Technische Universitaet Dresden and ESC Rennes School of Business. From 2012 to 2016, she worked as a research associate at the chair of Environmental Management and Accounting, Technische Universitaet Dresden and the University of New South Wales in Sydney. In 2017, she defended her dissertation focusing on the impacts of the natural environment, particularly climate change and resource scarcity, on corporate financial performance and on corporate responses to those impacts.

Julia Hillmann is a doctoral candidate at the Chair of Environmental Management and Accounting. She studied Business Administration at the Technische Universitaet Dresden. She is researching organizational resilience and was part of and held a scholarship of an interdisciplinary graduate school from the Leibniz Institute of Ecological Urban and Regional Development that consisted of doctoral candidates dealing with the concept of resilience from different perspectives. She was also part of the research project on regional climate change adaptation (REGKLAM). 
Prof. Dr. Edeltraud Guenther received her doctorate in Environmental Management Control from the Universitaet Augsburg and holds the Chair in Environmental Management and Accounting at the Technische Universitaet Dresden since 1996. She has been visiting professor at the University of Virginia's McIntire School of Commerce. Most recently, Prof. Guenther has initiated PRISMA, the Centre for Sustainability Assessment and Policy www.tu-dresden.de/prisma. 